\title{
Phosphate Transport by Reconstructed Monolayers from Cultured Mouse Kidney Cells
}

\author{
Yoshikazu KinOShITA, Masaaki FUKASE, Takahiro KUbOTA \\ AND TAKUO FUJITA
}

\begin{abstract}
Third Division, Department of Medicine, Kobe University School of Medicine. 7-5-1 Kusunoki-cho, Chuo-ku, Kobe 650, Japan
\end{abstract}

\begin{abstract}
A reconstructed monolayer was formed using epithelial cells from normal mouse kidney to investigate the hormonal effect on phosphate transport by the renal cells. The cells, when cultured on a Millipore filter, formed a monolayer with an apical negative transepithelial potential of $8.4 \pm 0.4 \mathrm{mV}$. When radioactive phosphate was added onto the apical surface of the monolayer (corresponding to the luminal surface of a renal tubule), the phosphate was transported through the cell layer to the basolateral surface (corresponding to the peritubular surface of a renal tubule). This transport process was saturable, energy-dependent, and inhibited by 2,4-dinitrophenol or ouabain. Dose-dependent parathyroid hormone-induced inhibition $(73 \%$ of the control) was also evident in this system. Similar inhibition (69\% of the control) was observed with DBcAMP. Thus, monolayers reconstructed from cultured mouse kidney cells show characteristics similar to those of renal tubules.
\end{abstract}

Renal tubular epithelial cells are organized into tubules in vivo. Usually, cultured epithelial cells form a continuous sheet in a unilateral direction, and, particularly, cultured renal tubular cells such as MDCK and $\mathrm{LLC}^{-\mathrm{PK}_{1}}$ cells were reported to form a polarized monolayer (Misfeldt et al., 1976; Cereijido et al., 1978; Rabito et al., 1984; Herzlinger and Ojakian, 1984). The apical surface, studded with microvilli, is considered to correspond to the luminal side. When cultured on a freely permeable filter, MDCK cells form an epithelial membrane which

Received January 6, 1987

Send reprint requests to Yoshikazu Kinoshita M. D. Third Division, Department of Medicine, Kobe University School of Medicine. 7-5-1 Kusunoki-cho, Chuo-ku, Kobe 650, Japan. Telephone 078-341-7451 transports water in an apical-to-basolateral direction and has transepithelial electrical potential, with the apical surface being negative (Misfeldt et al., 1976). Thus the characteristics of the cultured epithelial cells from kidneys are similar to those of the renal tubular cells.

In the present study, the formation of a reconstructed monolayer on a Millipore filter from cultured mouse renal epithelial cells was shown, and whether the phosphate transport through the monolayer is similar to that through renal tubules was investigated.

\section{Materials and Methods}

Cell Culture

A modification of our method previously 
reported (Fukase et al., 1982; Kinoshita et al., 1986) was used to obtain primary culture cells from mouse kidney. In brief, three to five-week old $\mathrm{C} 57 \mathrm{BL} / 6 \mathrm{~J}$ male mice were anesthesized with ether, the kidneys were removed and the medullae and papillae were dissected from the decapsulated kidneys. The remaining tissue was minced into pieces one millimeter in size. The tissue from four kidneys was suspended in calcium-supplemented (1 mM) Hanks' balanced salt solution with collagenase Type II (Worthington Biochemical Corp., Freehold, New Jersey), $3 \mathrm{mg} / \mathrm{ml}$, and hyaluronidase Type 1-S (Sigma Chemical Co., St. Louis), $4 \mathrm{mg} / \mathrm{ml}$, agitated in a metabolic shaker for $11 \mathrm{~min}$. The mixture was washed once with $40 \mathrm{ml}$ of a $15 \%$ solution of fetal calf serum
(FCS) (Grand Island Biological Co., New York) in Hanks' solution (calcium and magnesium free) and three times with Hanks' solution alone. Approximately $6 \times 10^{6}$ cells and tubule fragments in $30 \mathrm{ml}$ of supplemented medium were added to $75 \mathrm{~cm}^{2}$ culture flasks. The supplemented medium was a 1:1 mixture of Dulbecco's modified Eagle's MEM and Ham's F12 medium (SFFD) containing selenous acid (SA), $1.3 \mathrm{ng} / \mathrm{ml}$, transferrin (TF), $5 \mu \mathrm{g} / \mathrm{ml}$, insulin (INS), $5 \mu \mathrm{g} / \mathrm{ml}$ and prostaglandin $\mathrm{E}_{1}\left(\mathrm{PGE}_{1}\right), 50 \mathrm{ng} / \mathrm{ml}$. The medium was replaced every two days until the cells became confluent. After reaching confluency (approximately 7th culture day), the cells were dispersed with phosphate-buffered saline containing trypsin $(0.05 \%)$-EDTA $(0.02 \%)$ and washed

Fig. 1B

Fig. 1A
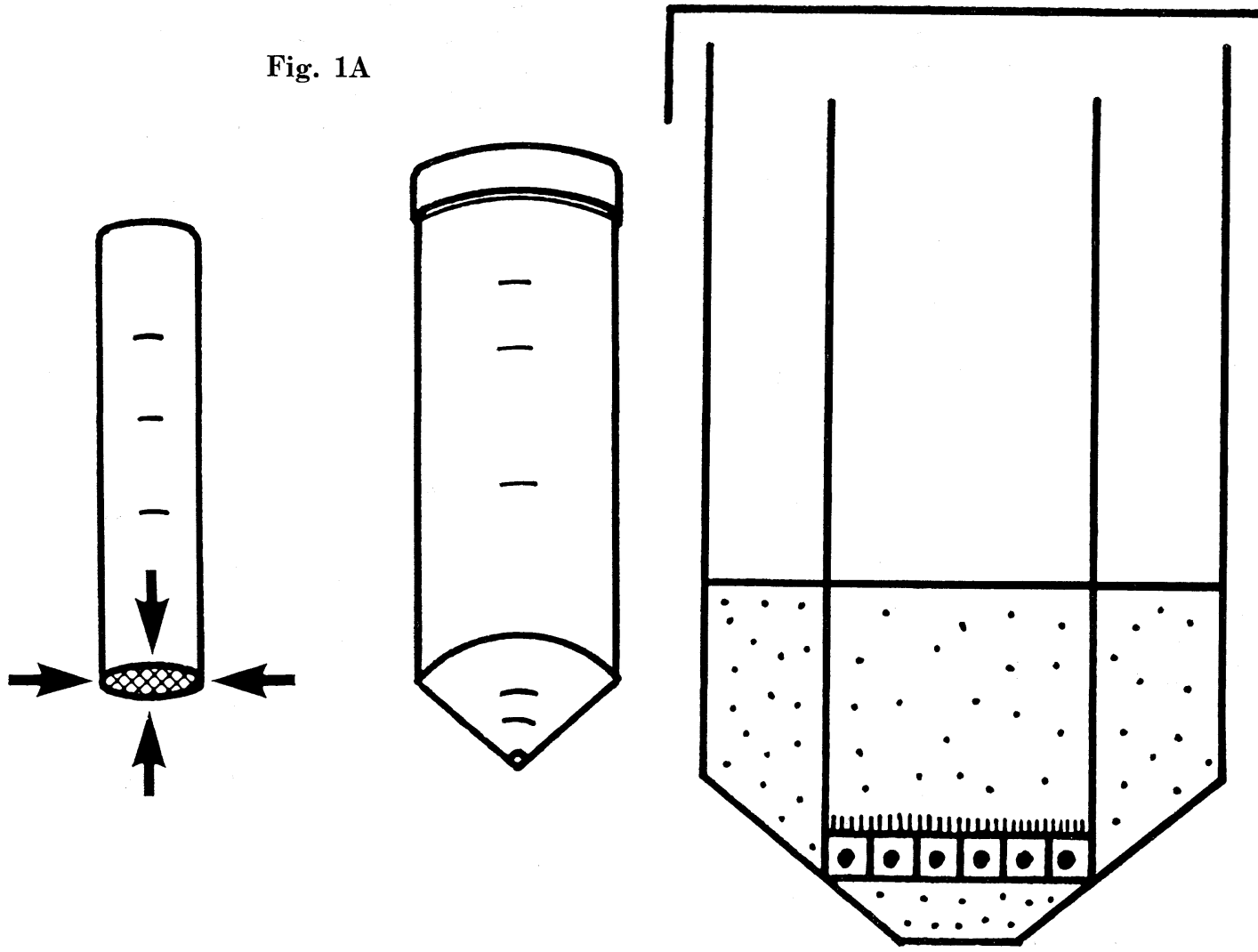

Fig. 1A, B. Plastic tube with a Millipore filter (arrows) and $50 \mathrm{ml}$ centrifuge tube (A). When the cells were cultured, the filter chamber was put in the centrifuge tube and the cells were inoculated onto the Millipore filter (B). 

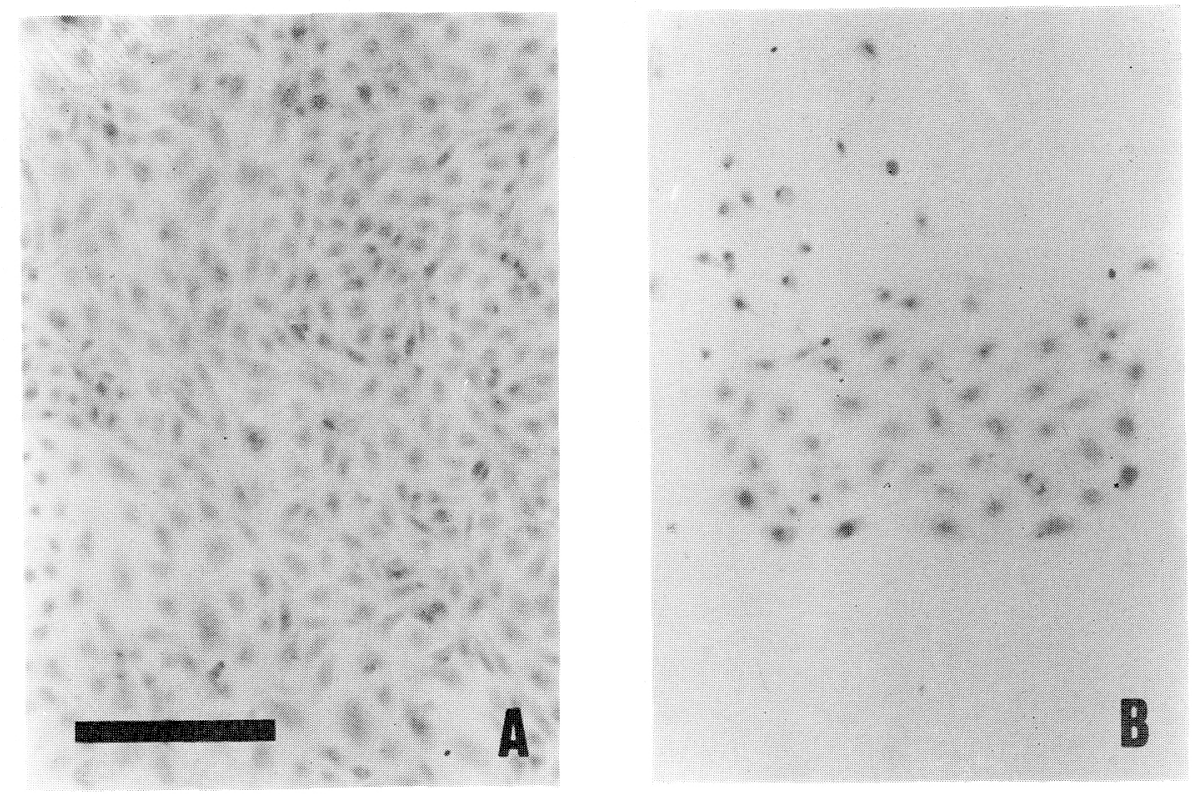

Fig. 2A, B. Photomicrographs of the cells cultured on the filter after staining (HematoxylinEosine staining, $\times 200)$ in the confluent $(A)$ and non-confluent state $(B)$. In the confluent state, the surface of the filter was covered completely with the cells, while there are areas not covered with cells in the subconfluent state. The bar represents $200 \mu \mathrm{m}$.

twice with SFFD supplemented with 5\% FCS. Two milliliters of the cell suspension $\left(10^{6}\right.$ cells $\left./ \mathrm{ml}\right)$ were inoculated in a plastic tube $(13 \mathrm{~mm}$ in diameter) equipped with a Millipore filter (HATF 02500) glued to its bottom, with the filter forming a permeable layer against the outside chamber. The tube equipped with the filter was placed in a chamber $(50 \mathrm{ml}$ centrifuge tube) containing 2 $\mathrm{ml}$ of a complete culture medium. The bottom of the outer chamber was conical, allowing free diffusion of the medium through the filter (Fig. 1A). SFFD supplemented with SA, TF, INS, $\mathrm{PGE}_{1}$, and $5 \%$ FCS was used as a culture medium. The medium was changed every day. After four days of culture, the cells were arranged in a tight monolayer (Fig. 1B), which was confirmed by microscopic examination of the filter after staining (Fig. 2A, B) and demonstration of a transepithelial potential difference by the cell layer.

\section{Hormone Preparations}

Synthetic human parathyroid hormone (1-34) (hPTH(1-34)) (3,130 units/mg) was kindly pro- vided by Toyo Jozo Co. Ltd. (Shizuoka, Japan) and used after being dissolved in $0.01 \mathrm{~N} \mathrm{HCl}$ containing $0.2 \%$ bovine serum albumin Fraction V (Sigma Chemical Co., St. Louis). Arginine vasopressin (AVP) was purchased from Protein Research Foundation (Minoh, Japan) and used after being dissolved in the same buffer as above. $\mathrm{N}^{6}, \mathrm{O}^{2 \prime}$-dibutyryl cyclic adenosine $3^{\prime}: 5^{\prime}$-monophosphate (DBcAMP) was provided by Yamasa Shyoyu Co. Ltd. (Chyoshi, Japan).

\section{Cell Counts and Protein Measurements}

The cells dispersed with trypsin-EDTA were counted with a hemocytometer. Viable cells were determined by the trypan blue dye exclusion method (Patterson, 1979). The protein content was measured by Lowry's method (Lowry et al., 1951).

Measurement of Transepithelial Potential Difference

A bridge of $3.0 \mathrm{M} \mathrm{KCl} / 3 \%$ agar in teflon tubing, connected to a $\mathrm{Ag}-\mathrm{AgCl}$ half-cell, was introduced into the medium on each side of the filter, and the trans-epithelial potential difference 
was measured with a differential electrometer (W. P. Instruments. model F223).

\section{Phosphate Transport through the Cell Layer}

When the cells reached confluency on the Millipore filter and were arranged in a tight monolayer, the culture medium was replaced with the experimental medium to ensure that no difference existed between the fluid levels in the filter tube and the outer chamber. The filter tube contained modified Ham's F12 medium (Ca 1.2 mM, P 0.1-3.0 mM) with ${ }^{32} \mathrm{P}$ (specific activity, $1 \mu \mathrm{Ci} / \mathrm{ml})$, and the outer chamber contained Ham's F12 medium (Ca $1.2 \mathrm{mM}, P \quad 0.3 \mathrm{mM}$ ) without ${ }^{32} \mathrm{P}$. After replacement of the medium, the cell layers were incubated for the appropriate period indicated in the "Results" at $4{ }^{\circ} \mathrm{C}$ or $37^{\circ} \mathrm{C}$ in $95 \%$ air and $5 \% \mathrm{CO}_{2}$. The amount of ${ }^{32} \mathrm{P}$ in the outer chamber was measured at the end of the incubation with a liquid scintillation counter. The amount of phosphate transported from the apical to the basolateral side through the cell layer was calculated from the concentration of ${ }^{32} \mathrm{P}$ in the medium in the outer chamber. The substances and hormones to be examined were added into the experimental medium.

\section{Compartmental Distribution of the Transported Phosphate}

To analyze the mechanism involved in the phosphate transport by the monolayer, the transported ${ }^{32} \mathrm{P}$ was fractionated into three broad categories: inorganic phosphate, acid-soluble organic phosphate, and acid-insoluble organic phosphate. The acid-soluble organic phosphate fraction contained low molecular organic phosphate compounds such as glycolytic intermediates and nucleotides. Acid-insoluble organic phosphate consisted of high molecular weight organic phosphate compounds such as nucleic acids, phospholipids, and phosphoprotein. The modified method of Rosenberg et al. (1980) was used to separate the phosphate compartments. After 4hour incubation, $500 \mu \mathrm{l}$ of the basolateral medium was mixed with $500 \mu \mathrm{l}$ of $10 \%$ trichloracetic acid (TCA). After centrifugation at $3000 \mathrm{rpm}$ for 10 min, the supernatant was separated, and the precipitate was washed with 5\% TCA. The precipitate was dissolved in $1 \mathrm{ml} 2 \mathrm{~N} \mathrm{NaOH}$, and ${ }^{32} \mathrm{P}$ was counted. To adjust the $\mathrm{pH}$ of the supernatants to 7.0, one drop of thymol blue and a neutralizing agent (a mixture of $100 \mathrm{ml}$ concentrated ammonium hydroxide and $40 \mathrm{ml}$ glacial acetic acid made up to 1 liter, to which $100 \mathrm{ml}$ of $0.4 \mathrm{M}$ sodium bicarbonate solution had been added) were added to each of the supernatants. Inorganic phosphate was precipitated by the addition of $2.5 \mathrm{ml} \mathrm{CaCl}$ solution (3.3\% $\mathrm{CaCl}_{2}$ in $33 \% \mathrm{CH}_{3} \mathrm{OH}$ ) followed by mixing; $0.15 \mathrm{ml} 0.04 \mathrm{M}$ sodium bicarbonate was then added, and the mixture was centrifuged. The supernatant was separated, and the precipitate was washed with $\mathrm{CaCl}_{2}$ solution and centrifuged. The second precipitate was then dissolved in $0.5 \mathrm{~N} \mathrm{HCl}$, and ${ }^{32} \mathrm{P}$ was counted in a liquid scintillation counter. Radioactivity in the combined supernatant was also counted.

\section{Statistical Analysis}

Duncan's new multiple range test (Duncan, 1955) was used for the statistical analysis.

\section{Results}

Transepithelial Potential Difference in the Cell Layer Reconstructed on the Filter

When the cells formed a monolayer on the millipore filter, the transepithelial potential difference between the apical and basolateral surface of the cell layer was $8.4 \pm$ $0.4 \mathrm{mV}$ at $37^{\circ} \mathrm{C}($ Mean \pm S.E., $\mathrm{n}=22)$. $\quad \overline{\mathrm{At}}$ $4^{\circ} \mathrm{C}$, no potential difference was measurable.

\section{Phosphate Transport through the Cell Layer on the Filter}

In Fig. 3, phosphate transport through the cell layer at $4^{\circ} \mathrm{C}$ and $37^{\circ} \mathrm{C}$ was plotted as a function of time, with the phosphate concentration of both the apical and basolateral medium maintained at $0.3 \mathrm{mM}$. At $37^{\circ} \mathrm{C}$, transported phosphate increased linearly from $(1.3 \pm 0.2) \times 10^{-10} \mathrm{moles} / \mathrm{cm}^{2}$ at $5 \mathrm{~min}$ to $(26.9 \pm 2.7) \times 10^{-10} \mathrm{moles} / \mathrm{cm}^{2}$ at 4 hours. Therefore, a 4-hour incubation period was used for the following transport study. After 4-hour incubation, $99.5 \%$ of the transported phosphate in the basolateral medium was inorganic and only $0.5 \%$ was organic phosphate (Table 1). Table 2 shows the effect of temperature, 2,4-dinitrophenol $(2,4 \mathrm{DNP})$, ouabain or sodium-free medium 


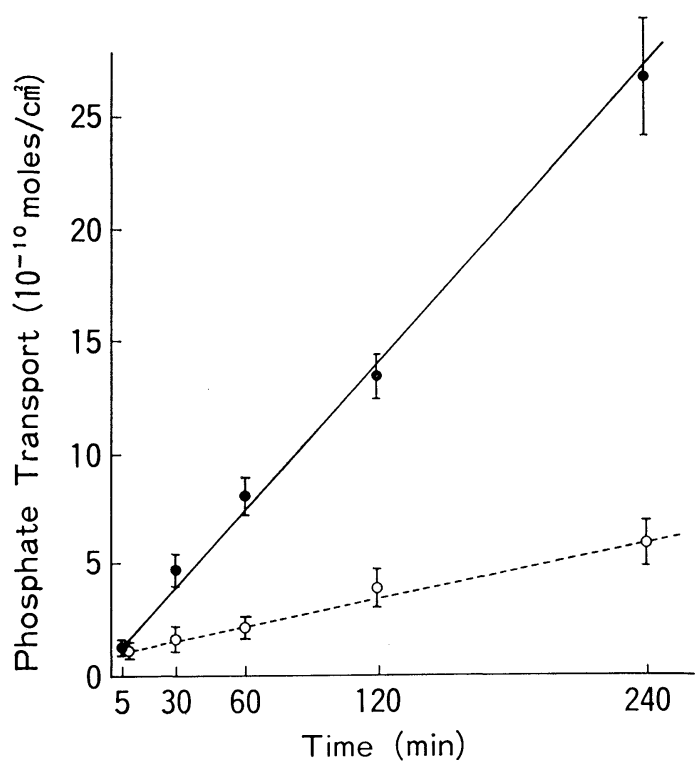

Fig. 3. The time course of phosphate transport from the apical to basolateral medium through the cell layer at $37^{\circ} \mathrm{C}(-)$ ) or $4^{\circ} \mathrm{C}(\mathrm{O}-$ -- $)$. Phosphate transport increased linearly at both $37^{\circ} \mathrm{C}$ and $4^{\circ} \mathrm{C}$. Vertical lines represent the mean \pm S. E. Determinations were made in four different plates. on the phosphate transport. In this experiment, modified Ham's F12 medium (Ca $1.2 \mathrm{mM}, \mathrm{P} 0.3 \mathrm{mM}, \mathrm{pH}$ 7.4) was used for both the apical and basolateral sides. When incubated at $4^{\circ} \mathrm{C}$, the phosphate transport was reduced to $24 \%$ at 1 hour and to $37.4 \%$ at 4 hours of the values $[(7.4 \pm 0.9)$ $\times 10^{-10}$ moles $/ \mathrm{cm}^{2} / \mathrm{hr}$ and $(27.5 \pm 0.7) \times 10^{-10}$ moles $/ \mathrm{cm}^{2} / 4 \mathrm{hrs}$, respectively, $\mathrm{n}=5$ ] obtained at $37^{\circ} \mathrm{C}$. The addition of $2,4 \mathrm{DNP}, 10^{-3} \mathrm{M}$

Table 1. Compartmental Distribution of Transported Phosphate during 4 Hours Incubation

\begin{tabular}{lc}
\hline \hline & Percent distribution \\
\hline inorganic phosphate & $99.5 \pm 0.1$ \\
TCA non-precipitable & $0.3 \pm 0.1$ \\
organic phosphate & $0.2 \pm 0.1$ \\
TCA precipitable & \\
organic phosphate & \\
\hline
\end{tabular}

The transported phosphate in the basolateral medium during 4 hours incubation was divided into three compartments. Values are the means \pm S. E. for 6 different cultures.

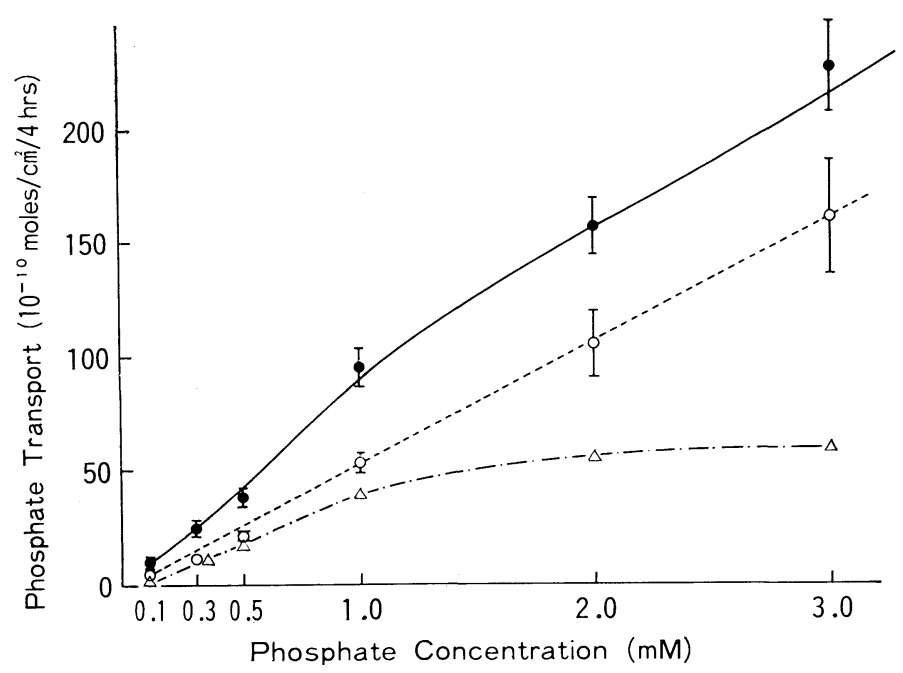

Fig. 4. Effect of phosphate concentrations in the apical medium on the phosphate transport through the cell layer at $37^{\circ} \mathrm{C}(-)$ ) or $4^{\circ} \mathrm{C}(\bigcirc-\bigcirc)$. The line $(\triangle-\cdot-\triangle)$ representing the value obtained by subtracting the phosphate transport at $4^{\circ} \mathrm{C}$ from that at $37^{\circ} \mathrm{C}$ was considered to be the active transport. Vertical lines represent the mean \pm S. E. Determinations were made in eight different plates. 
Table 2. Effect of 2,4DNP, Ouabain, Low Incubation Temperature and Sodium-Free Medium on Phosphate Transport

\begin{tabular}{|c|c|c|c|}
\hline & & $\begin{array}{l}\text { Percent change } \\
\text { from control }\end{array}$ & $P$ value \\
\hline \multicolumn{4}{|l|}{1 hour incubation } \\
\hline 2,4DNP $\left(10^{-3} \mathrm{M}\right)$ & (4) & $-43.3 \pm 13.6$ & $<0.01$ \\
\hline Ouabain $\left(10^{-4} \mathrm{M}\right)$ & (4) & $-51.6 \pm 7.9$ & 0.01 \\
\hline $4^{\circ} \mathrm{C}$ & (4) & $-76.0 \pm 1.8$ & $<0.01$ \\
\hline $4^{\circ} \mathrm{C}+2,4 \mathrm{DNP}\left(10^{-3} \mathrm{M}\right)$ & (7) & $-76.0 \pm 1.0$ & $<0.01$ \\
\hline $4^{\circ} \mathrm{C}+$ ouabain $\left(10^{-4} \mathrm{M}\right)$ & (7) & $-74.7 \pm 1.3$ & $<0.01$ \\
\hline Sodium free medium & (8) & $-60.7 \pm 2.2$ & $<0.01$ \\
\hline \multicolumn{4}{|l|}{4 hours incubation } \\
\hline 2,4DNP $\left(10^{-3} \mathrm{M}\right)$ & (4) & $-52.9 \pm 12.2$ & $<0.01$ \\
\hline Ouabain $\left(10^{-4} \mathrm{M}\right)$ & (4) & $-49.1 \pm 10.1$ & $<0.01$ \\
\hline $4^{\circ} \mathrm{C}$ & (4) & $-62.6 \pm 0.7$ & $<0.01$ \\
\hline $4^{\circ} \mathrm{C}+2,4 \mathrm{DNP}\left(10^{-3} \mathrm{M}\right)$ & & $-64.1 \pm 1.6$ & $<0.01$ \\
\hline $4^{\circ} \mathrm{C}+$ ouabain $\left(10^{-4} \mathrm{M}\right)$ & & $-60.3 \pm 1.0$ & $<0.01$ \\
\hline Sodium free medium & & $-67.9 \pm 1.4$ & $<0.01$ \\
\hline
\end{tabular}

Values are the means $\pm S$. E. Values in parentheses denote the number of experiments. The amounts of phosphate transported at $37^{\circ} \mathrm{C}$ without any inhibitor are

$(7.4 \pm 0.9) \times 10^{-10} \mathrm{moles} / \mathrm{cm}^{2} / \mathrm{hr}$ and

$(27.5 \pm 0.7) \times 10^{-10} \mathrm{moles} / \mathrm{cm}^{2} / 4 \mathrm{hrs}$ $(\mathrm{n}=5$, mean \pm S. E.).

All experiments except the $4^{\circ} \mathrm{C}$ study were carried out at $37^{\circ} \mathrm{C}$.

or ouabain, $10^{-4} \mathrm{M}$ to both the apical and basolateral medium at $37^{\circ} \mathrm{C}$ reduced the phosphate transport to $56.7 \%$ and $48.4 \%$, respectively, to those of the control at 1 hour, and to $47.1 \%$ and $50.9 \%$, respectively, to those of the control at 4 hours. At $4^{\circ} \mathrm{C}$, no further inhibition of phosphate transport by 2,4DNP and ouabain was observed (Table 2). When sodium chloride in the medium in the inside chamber was completely replaced with choline chloride on an equimolar basis, phosphate transport was depressed to $32.1 \%$ of the control value at 4 hours' incubation. Fig. 4 shows the relationship between phosphate concentrations of the apical medium over the range of $0.1-3.0 \mathrm{mM}$ and the rate of phosphate transport from the apical to the basolateral medium. The phosphate concentration in

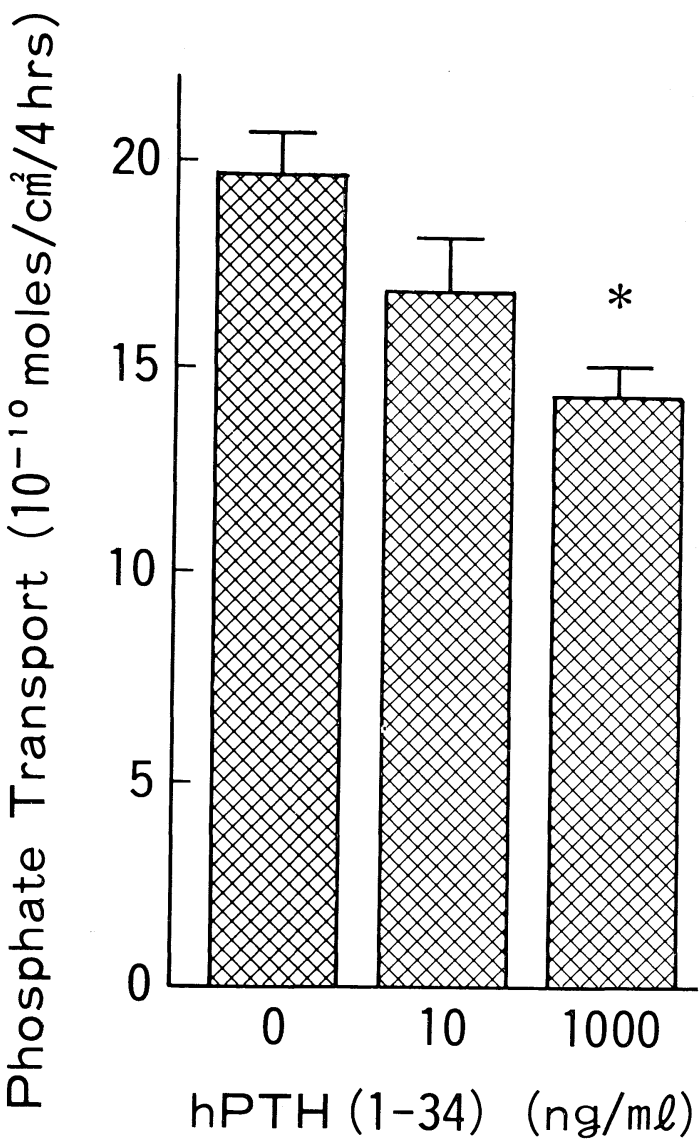

Fig. 5. Effect of hPTH(1-34) on the phosphate transport from the apical to the basolateral medium. In the presence of hPTH(1-34), the phosphate transport was inhibited. Mean \pm S. E. for six different plates.

* $\mathbf{P}<0.01$ significantly different from the control.

the basolateral medium was kept constant at $0.3 \mathrm{mM}$. Phosphate transport increased in proportion to the increase in the concentration of phosphate in the apical medium at both $4^{\circ} \mathrm{C}$ and $37^{\circ} \mathrm{C}$. To estimate the active phosphate transport through the monolayer, the line representing the values obtained by subtracting the phosphate transport at $4^{\circ} \mathrm{C}$ from that at $37^{\circ} \mathrm{C}$ was calculated. The system as a function of phosphate 
concentrations over the range of $0.1-3.0$ $\mathrm{mM}$ appeared to be saturable. As shown in Fig. 5, the addition of hPTH $(1-34)$ to the basolateral medium decreased phosphate transport, and when incubated with 1,000 $\mathrm{ng} / \mathrm{ml} \mathrm{hPTH}(1-34)$, phosphate transport was only $73 \%$ of that of the control. Furthermore, when $10^{-3} \mathrm{M}$ DBcAMP was added to the basolateral medium, inhibition of phosphate transport was alsc observed $(68.9 \%$ of the control). AVP $1 \mu \mathrm{g} / \mathrm{ml}$ did not change the phosphate transport (Table 3 ).

Table 3. Effect of Human PTH(1-34), DBcAMP and Arginine Vasopressin on Phosphate Transport

\begin{tabular}{lrrr}
\hline \hline & & $\begin{array}{c}\text { Percent change } \\
\text { from control }\end{array}$ & P value \\
\hline hPTH(1-34)(1 $\mu \mathrm{g} / \mathrm{ml})$ & $(7)$ & $-21.8 \pm 3.5$ & $<0.01$ \\
DBcAMP $\left(10^{-3} \mathrm{M}\right)$ & $(7)$ & $-31.1 \pm 3.5$ & $<0.01$ \\
AVP $(1 \mu \mathrm{g} / \mathrm{ml})$ & $(5)$ & $+3.4 \pm 10.1$ & N.S. \\
\hline
\end{tabular}

Values are the means $\pm S$. E. Values in parentheses denote the number of experiments. The amount of phosphate transported without any inhibitor is $(27.5 \pm 0.7) \times 10^{-10} \mathrm{moles} / \mathrm{cm}^{2} / 4 \mathrm{hrs}(\mathrm{n}=$ 5 , mean \pm S. E.). Substances to be tested were added to the basolateral medium.

\section{Discussion}

Reconstructed monolayers prepared by our simple procedure described in this paper developed a potential difference, and transported phosphate from the apical to the basolateral surface. Lowering of the incubation temperature, the use of sodiumfree medium in the apical chamber, or the addition of 2,4DNP, ouabain, hPTH(1-34), and DBcAMP decreased the phosphate transport. The development of a transepithelial potential difference and evidence of energy-dependent, sodium-dependent, PTHand DBcAMP-suppressible phosphate transport showed that these monolayers retain some characteristics of renal tubules.

Although phosphate transport through the renal tubular cells is well understood, there are many conflicting data concerning the action of various hormones on phosphate transport (Bank and Malnic, 1980; Lau et al., 1980 ; Ritz et al., 1980). This predicament is considered to be due mainly to the lack of an ideal system making possible the investigation of hormonal actions on the renal tubular phosphate transport in vitro without interference by the homeostatic systems of the body. Phosphate uptake into the brush border membrane vesicles has been widely used as a method for the in vitro study of phosphate transport. However, since the hormones to be investigated must be administered to the animal before the preparation of the brush border membrane vesicles (Evers et al., 1978; Hammerman et al., 1980), the hormones not only affect the renal phosphate handling directly, but also indirectly by changing the plasma levels of other hormones and minerals. Although LLC-PK $_{1}$ cells have been used as a model of proximal tubules for studying renal phosphate transport, the following two factors may limit this use of these cells; 1) Positive response to calcitonin and vasopressin by increasing adenosine $3^{\prime}: 5^{\prime}$-cyclic monophosphate (cAMP) production (Goldring et al., 1978). 2) The controversial response of phosphate uptake to PTH (Noronha-Blob et al., 1984; Caverzasio et al., 1985).

In the present study, we employed cultured epithelial cells obtained from mouse kidney to study whether the monolayers reconstructed by these cells transport phosphate from the apical to the basolateral side or not. These cultured cells were a mixture of cells of various renal tubular segments and responded strongly to PTH, calcitonin, and weakly to vasopressin by increasing cAMP content as previously reported (Fukase et al., 1984 ; Kinoshita et al., 1985). The alkaline phosphatase activity in the cultured cells, a marker enzyme of the proximal convoluted tubules of mouse nephrons, was only $5 \%$ of that in the kidney 
cortex, and was less than $10 \%$ of that in LLC-PK ${ }_{1}$ cells (Rabito et al., 1984 ; Kinoshita et al., 1986). Thus, the population of proximal tubular cells was probably small in this monolayer. The cultured cells employed in this study were epithelial in morphology and formed many domes (Kinoshita et al., 1986), suggesting the existence of fluid transport from the apical to the basolateral surface (Lever, 1979). Furthermore, when cultured on a permeable filter, the cells constructed a monolayer with a high apical negative transepithelial potential similar to that of distal renal tubules (Imai, 1984). Therefore, the apical side of this monolayer may correspond to the luminal surface of the renal tubules and this monolayer might be suitable for the investigation of phosphate transport from the apical side to the basolateral side.

The data presented here are consistent with the generally accepted view that phosphate reabsorption at the renal tubules is energy and sodium dependent (Mizgala and Quamme, 1985), since phosphate transport was inhibited by low incubation temperature, 2,4DNP (inhibitor of aerobic ATP production), ouabain (inhibitor of $\mathrm{Na}, \mathrm{K}$-ATPase on the basolateral membrane of the cells), and sodium-free medium in the apical chamber (Table 2).

It is well known that PTH stimulates cAMP production and inhibits phosphate reabsorption at the renal tubules. Indeed, a similar result was also obtained in our system (Figure 5) (Kinoshita et al., 1985). Furthermore, DBcAMP inhibited phosphate transport through the monolayer. Therefore, PTH might also inhibit phosphate transport in our system through cAMP production as in the renal tubules. Although vasopressin increased cAMP production by the monolayer (Kinoshita et al., 1985), it did not change the phosphate transport. Since the monolayer was composed of heterogenous cells, it is possible that vasopressin and $\mathrm{PTH}$ stimulate the cAMP production of different kinds of cells within the monolayer.

The monolayers produced for use in this study did not consist of homogeneous cells but were heterogeneous, mainly composed of distal tubular cells. Therefore, further study will be required to characterize them, yet the fact remains that they are similar in their ability to transport phosphate to the renal tubules.

\section{Acknowledgements}

This work was supported in part by a grant to the Investigation Committee on Abnormality in Hormone Receptor Mechanism from the Ministry of Health and Welfare of Japan.

\section{References}

Bank, N. and G. Malnic (1980). Effect of urinary alkalinization on renal phosphate reabsorption. In : Renal Handling of Phosphate (S. G. Massry and H. Fleisch eds), Plenum Press, New York. pp. 209-241.

Caverzasio, J., C. D. A. Brown, J. Biber, J. P. Bonjour and H. Murer (1985). Adaptation of phosphate transport in phosphate-deprived LLC-PK $_{1}$ cells. Am. J. Physiol. 248, F122F127.

Cereijido, M., E. S. Robbins, W. J. Dolan, C. A. Rotunno and D. D. Sabatini (1978). Polarized monolayers formed by epithelial cells on a permeable and translucent support. $J$. Cell. Biol. 77, 853-880.

Duncan, D. B. (1955). The multiple range and multiple $\mathrm{F}$ tests. Biometrics. 11, 1.

Evers, C., H. Murer and R. Kinne (1978). Effect of parathyrin on the transport properties of isolated renal brush-border vesicles. Biochem. J. 172, 49-56.

Fukase, M., S. J. Birge, L. Rifas, L. V. Avioli and L. R. Chase (1982). Regulation of 25 hydroxyvitamin $D_{3}$ 1-hydroxylase in serumfree monolayer culture of mouse kidney. Endocrinology. 110, 1073-1075.

Fukase, M., L. V. Avioli, S. J. Birge and L. R. Chase (1984). Abnormal regulation of 25hydroxyvitamin $\mathrm{D}_{3}-1 \alpha$-hydoxylase activity by calcium and calcitonin in renal cortex from 
hypophosphatemic (Hyp) mice. Endocrinology. 114, 1203-1207.

Goldring, S. R., J. M. Dayer, D. A. Ausiello and S. M. Krane (1978). A cell strain cultured from porcine kindney increases cyclic AMP content upon exposure to calcitonin or vasopressin. Biochim. Biophys. Res. Commun. 83, 434-440.

Hammerman, M. R., I. E. Karl and K. A. Hruska (1980). Regulation of canine renal vesicle $\mathbf{P i}$ transport by growth hormone and parathyroid hormone. Biochim. Biophys. Acta. 603, 322-335.

Herzlinger, D. A. and G. K. Ojakian (1984). Studies on the development and maintenance of epithelial cell surface polarity with monoclonal antibodies. J. Cell. Biol. 98, 17771787.

Imai, M. (1984). Electrolite transport by the renal tubules. Medical Clinics of Japan. 10, 32-36. (In Japanese).

Kinoshita, Y., M. Fukase, M. Takenaka, M. Nakada, A. Miyauchi and T. Fujita (1985). Calcitonin-responsive clonal cell line from porcine kidney $(\mathrm{PK}(15))$ in serum-free medium. Endocrinol. Japon. 32, 819-828.

Kinoshita, Y., M. Fukase, A. Miyauchi, M. Takenaka, M. Nakada and T. Fujita (1986). Establishment of a parathyroid hormoneresponsive phosphate transport system in vitro using cultured renal cells. Endocrinology. 119, 1954-1963.

Lau, K., S. Goldfarb and M. Goldberg (1980). The effects of parathyroid hormone on renal phosphate handling. In: Renal Handling of Phosphate (S. G. Massry and H. Fleisch eds), Plenum Press, New York. pp. 115-135.

Lever, J. E. (1979). Regulation of dome formation in differentiated epithelial cell cultures.
J. Supramolecular Structure. 12, 259-272.

Lowry, O. H., N. J. Rosenbrough, A. L. Farr and R. J. Randall (1952). Protein measurement with the folin phenol reagent. J. Biol. Chem. 193, 256-275.

Misfeldt, D. S., S. T. Hamamoto and D. R. Pitelka (1976). Transepithelial transport in cell culture (renal epithelium). Proc. Natl. Acad. Sci. USA. 73, 1212-1216.

Mizgala, C. L. and G. A. Quamme (1985). Renal handling of phosphate. Physiol. Review. 65, 431-466.

Noronha-Blob, L., C. Filburn and B. Sacktor (1984). Phosphate uptake by kidney epithelial (LLC-PK ${ }_{1}$ ) cells. Arch. Biochem. Biophys. 234, 265-274.

Patterson, M. K. Jr. (1979). Measurement of growth and viability of cells in culture. In : Methods in Enzymology Volume LVIII Cell Culture (W. B. Jakoby and I. H. Pastan eds), Academic Press, New York. pp. 141-152.

Rabito, C. A., J. I. Kreisberg and D. Weight (1984). Alkaline phosphatase and r-glutamyl transpeptidase as polarization markers during the organization of LLC-PK $_{1}$ cells into an epithelial membrane. J. Biol. Chem. 259, 574582.

Ritz, E., W. Kreusser and J. Bommer (1980). Effects of hormones other than parathyroid hormone on renal handling of phosphate. In : Renal Handling of Phosphate (S. C. Massry and H. Fleisch eds), Plenum Press, New York. pp. 137-195.

Rosenberg, E. M., S. W. Lee, L. R. Chase and L. V. Avioli (1980). Phosphate accumulation by the isolated renal tubule and the effect of parathyroid hormone and cyclic adenosine monophosphate. J. Lab. Clin. Med. 96, 2435. 